\title{
Food web structure of the benthic community at the Porcupine Abyssal Plain (NE Atlantic): a stable isotope analysis
}

\author{
K. Iken ${ }^{a, *}$, T. Brey ${ }^{a}$, U. Wand ${ }^{b}, J_{\text {. Voigt }}{ }^{c}$, P. Junghans ${ }^{c}$ \\ a Alfred Wegener Institute for Polar and Marine Research, Columbusstrasse, 27568 Bremerhaven, Germany \\ ${ }^{\mathrm{b}}$ Alfred Wegener Institute for Polar and Marine Research, Telegrafenberg A 43, 14473 Potsdam, Germany \\ ${ }^{c}$ Research Institute for the Biology of Farm Animals, Research Unit Nutritional Physiology 'Oskar Kellner', Justus-von-Liebig- \\ Weg 2, 18059 Rostock, Germany
}

\begin{abstract}
The deep-sea benthic community at the Porcupine Abyssal Plain (NE Atlantic) is a highly food limited system. The annual input of sedimenting phytodetritus, which reaches the sea floor around May/June, is the major input of energy. The relative trophic position of the most abundant components of the benthos (90 species or higher taxonomic groups), including meiofaunal, macrofaunal, and megafaunal organisms, was evaluated by stable isotope analysis. The majority of the macro- and megafaunal organisms investigated were deposit feeders $(N=35)$, less numerous were suspension feeders $(N=17)$ and predators/scavengers $(N=29)$. Stable nitrogen values overlap and cover a large range within feeding types, indicating a strong overlap in food sources and a high degree of competition for food. Suspension feeders, mainly cnidarians, have a broad trophic spectrum through feeding on resuspended material as well as capturing pelagic prey; thus during the greater part of the year they can compensate for any shortage in sedimenting fresh POM. Benthic deposit feeders use a variety of feeding strategies to exploit their common food resource. The holothurians, the dominant megabenthic group at PAP, included some highly mobile species, which seem to be quite efficient in tracing and exploiting localised patches of nutritious phytodetritus. Other holothurian species, however, forage successfully on more refractory material, possibly assisted by enteric bacteria. Predators/scavengers fall into two groups, representing two major trophic pathways. Firstly, several of the invertebrate predators prey on deposit-feeding organisms and so are the end consumers of an exclusively benthic food web. Secondly, there are highly mobile benthopelagic predators/scavengers, which are a major link with the benthopelagic food web through their feeding on pelagic prey.

Generally, within the benthic community at PAP competition for food is reduced by two alternative evolutionary adaptations: (1) specialization on slightly different food sources and (2) vertical expansion of the trophic spectrum. This leads to a rather complex food web, covering a total $\delta^{15} \mathrm{~N}$ range of at least 10\%. () 2001 Elsevier Science Ltd. All rights reserved.
\end{abstract}

* Corresponding author. Present address: University of Alabama at Birmingham, Department of Biology, 1300 University Boulevard, Birmingham, AL 35294-1170, USA. Fax: +1-205-975-6097.

E-mail address: iken@uab.edu (K. Iken). 


\section{Contents}

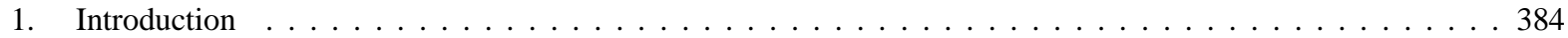

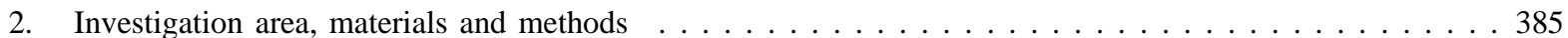

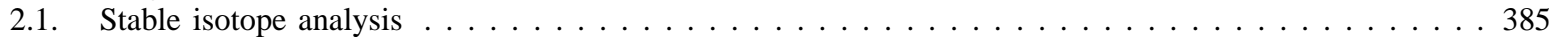

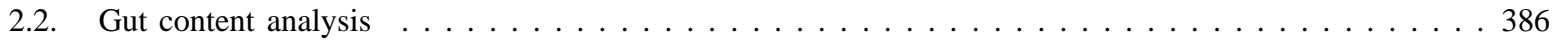

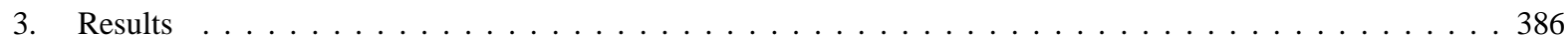

4. Discussion . . . . . . . . . . . . . . . . . . . . . . . . . . . . . . 395

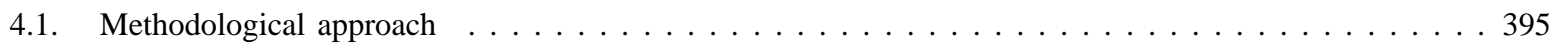

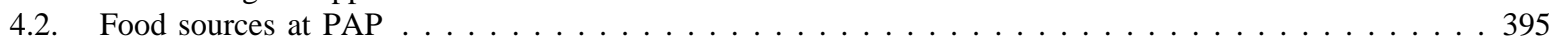

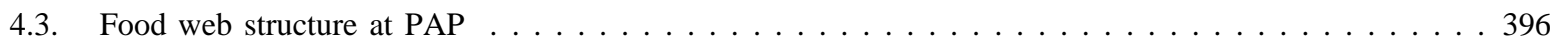

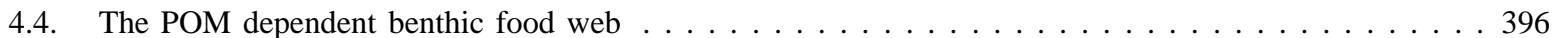

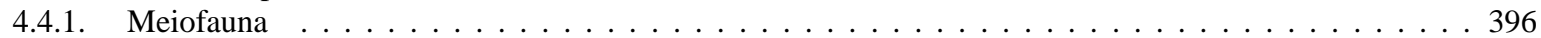

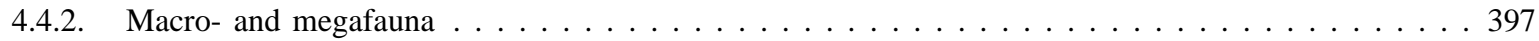

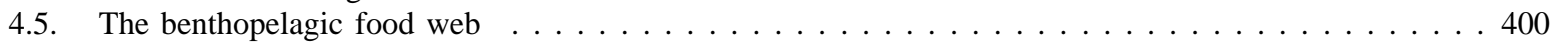

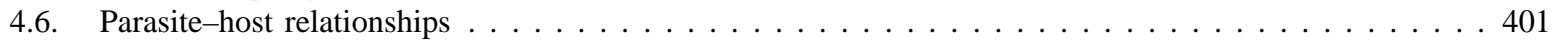

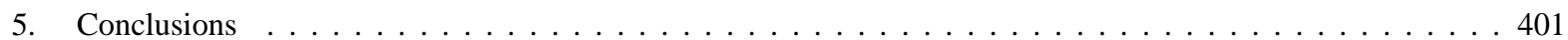

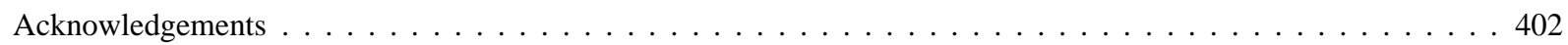

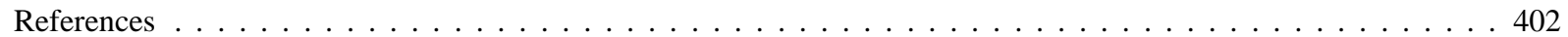

\section{Introduction}

The deep-sea floor is considered to be the world's largest sink for biogenic carbon. Deposition of particles produced in the overlying water column creates an important paleontological record. But particle deposition onto the abyssal seabed, especially of phytodetritus, is of interest not only geologically but also biologically.

The Porcupine Abyssal Plain (PAP) in the north-east Atlantic is characterized by a strong seasonal flux of particulate organic matter (POM), which is mainly derived from primary production in the eutrophic epipelagic zone (Rice, Thurston, \& Bett, 1994). The central region of the PAP is largely unaffected by slope processes, and the downward flux is nearly vertical (Billett, Lampitt, Rice, \& Mantoura, 1983). During sedimentation, the particles are subject to degradation and so their biochemical composition changes (e.g. Wakeham, Hedges, Lee, Peterson, \& Hernes, 1997). Though many nutrients are lost from POM during sedimentation, phytodetrital deposition is considered the major energy input driving the dynamics of the benthic community (Pfannkuche, 1993; Gooday \& Turley, 1990; Gooday, 1988; Fowler \& Knauer, 1986). Benthic deep-sea communities are found to be species-rich, abundant and productive (reviewed by Rowe, 1983) and their diversity is described as being equal in diversity to rain-forests and tropical systems (e.g. Grassle, Maciolek, \& Blake, 1990). Although meiofauna, especially foraminiferans, account for a large proportion of this high species diversity (Gooday, 1986), macrofaunal species, especially polychaetes, contribute significantly to the richness of benthic communities (Cosson, Sibuet, \& Galéron, 1997). At PAP, holothurians account for more than $90 \%$ of the megafauna, and together with other echinoderms, they represent the dominant group in terms of both biomass and numerical abundance (Thurston, Bett, Rice, \& Jackson, 1994; Billett, 1991). However, how the abyssal community is sustained despite the restricted energy input from the water column is still poorly understood (Smith, 1987). Our knowledge of the feeding 
ecology of single deep-sea species is steadily increasing, even so the overall structure of deep-sea food webs remains to be fully investigated. The majority of species are reported to be deposit feeders, ingesting and reworking vast amounts of sediment. Consequently, competition for food is expected to be extremely high. On the other hand, in a severely food limited system, we would expect the development of feeding strategies which would serve either to reduce or to avoid competition.

Traditional approaches to food web analysis usually include gut content analysis, together with field and laboratory observations. The approaches are difficult when studying the deep-sea because of restricted accessibility (low temporal and spatial resolution) as well as technical problems: Live organisms for experimental studies are difficult to obtain and gut content analyses are hampered by specimens being damaged during sampling and pressure effects. More recently, stable isotope analysis has been established as an alternative approach to investigate relative trophic positions of organisms (e.g. Fry \& Sherr, 1988; Owens, 1987; Peterson \& Fry, 1987). It has been proved in both experimental and field studies that naturally occurring stable isotopes of carbon and nitrogen show a stepwise enrichment between prey and consumer tissue during assimilation processes (Fry, 1988; Minagawa \& Wada, 1984; Rau, 1982; DeNiro \& Epstein 1978, 1981). Selective metabolic fractionation leads to a preferential loss of lighter isotopes during respiration (carbon) and excretion (nitrogen) (DeNiro \& Epstein, 1978; Rau et al., 1983; Tieszen, Boutton, Tesdahl, \& Slade, 1983). Isotopic enrichment in consumer tissue compared to the prey tissue allows the relative trophic positions of members of a food web to be established. Isotopic enrichment, however, depends on turnover rates of tissues and will vary with tissue type. 'Long lived' tissues such as muscle integrate isotope ratios over the post-metamorphic lifetime of an organism. Isotope ratios of tissues with faster turnover such as gonads will reflect the specific diet during the shorter period of tissue formation. Hence, to establish relative trophic positions within a food web the same tissue type should always be compared. Based on these earlier studies, Hobson and Welch (1992) established mean enrichment steps for ${ }^{13} \mathrm{C}$ and ${ }^{15} \mathrm{~N}$ between subsequent trophic levels in marine benthic systems as $1 \%$ and $3.8 \%$, respectively.

Within the joint European MAST III program BENGAL (High resolution temporal and spatial study of the BENthic biology and Geochemistry of a north-eastern Atlantic abyssal Locality), the present study aims to clarify the trophic structure within the benthic community at PAP. Both stable isotope and gut content analyses are used to investigate whether species occurring at PAP have developed strategies which serve to reduce competition for limited food resources.

\section{Investigation area, materials and methods}

The investigation area was the Porcupine Abyssal Plain (PAP) in the north-eastern Atlantic (centered on $48^{\circ} 50^{\prime} \mathrm{N} 16^{\circ} 30^{\prime} \mathrm{W}$ ) southwest of Ireland with a depth of about $4840 \mathrm{~m}$ (Billett \& Rice, 2001). The location is known to be subjected to a regular seasonal deposition of aggregated POM which normally reaches the seafloor in May/June. This annual input characterizes this deep-sea plain as being relatively eutrophic (Rice et al., 1994).

\subsection{Stable isotope analysis}

Samples for stable isotope analysis were collected during two cruises of RRS Discovery to the PAP site in September 1996 (cruise D222) and July 1997 (cruise D229). Particulate organic matter (POM) was collected using a stand-alone pumping system (SAPS) on GF/C glass-fiber filters (particle retention about $1.2 \mu \mathrm{m}$ ) from $40 \mathrm{~m}$ depth. Meiofauna and macrofauna were sampled from the upper 3-5 cm layer of sediment collected with both box and multiple cores. Megafaunal samples were obtained from trawling the sea floor with a semi-balloon otter trawl (OTSB). Amphipods were sampled with baited traps deployed either immediately above the bottom or at about $30 \mathrm{~m}$ above bottom (mab). The bait was protected to 
prevent amphipods from feeding. Parasitic species were obtained from several megafaunal organisms; these included both ectoparasites from crustaceans, holothurians, and fish and nematodes and trematodes recovered from fish intestines.

For meiofaunal taxa (e.g. nematodes, harpacticoids, foraminiferans) several complete individuals were pooled to obtain sufficient mass for the isotope measurements. Larger species of the macro- and megafauna were dissected and their guts were removed. Then pieces of body wall (e.g. in cnidarians and holothurians) or muscle tissue (e.g. in fish) were taken for analysis (Table 1). In a few asteroids and ophiuroids gonad tissue was sampled because insufficient organic material could be obtained from the body wall. All samples were kept frozen at $-30^{\circ} \mathrm{C}$ before freeze drying. The dried samples were then ground to a homogeneous powder, and treated with $2 \mathrm{~N} \mathrm{HCl}$ to remove carbonates, and dried again prior to isotope measurement. The possible number of isotope measurements was limited so individual samples of each species were pooled so that the isotopic values reported represented the means of a given number of individuals. In some species replicates were measured.

${ }^{13} \mathrm{C} /{ }^{12} \mathrm{C}$ measurements were conducted using a Finnigan MAT Delta $\mathrm{S}$ mass spectrometer which was coupled to an elemental analyzer (CHN-O Rapid, Heraeus) (Fry, Brand, Mersch, Tholke, \& Garritt, 1992). Measurements were standardized to Vienna-PDB. Analytical reproducibility was better than $\pm 0.20 \%$ o ${ }^{15} \mathrm{~N} /{ }^{14} \mathrm{~N}$ measurements were performed with a Finnigan MAT Delta $\mathrm{S}$ mass spectrometer which was coupled to an elemental analyzer (EA 1108, Carlo-Erba). Measurements were standardized to atmospheric $\mathrm{N}_{2}$, and analytical error was about $\pm 0.15 \%$ o. Stable isotope ratios were expressed in the conventional $\delta$ notation as parts per thousand $(\% \circ)$ according to the following equation:

$$
\delta X=\left[\left(R_{\text {sample }} / R_{\text {standard }}\right)-1\right] \cdot 1000
$$

where $X$ is ${ }^{13} \mathrm{C}$ or ${ }^{15} \mathrm{~N}$ and $R$ is the corresponding ratio ${ }^{13} \mathrm{C} /{ }^{12} \mathrm{C}$ or ${ }^{15} \mathrm{~N} /{ }^{14} \mathrm{~N}$. According to literature data (Hobson \& Welch, 1992) trophic level enrichment factors are about $1 \%$ or for $\delta^{13} \mathrm{C}$ and $3.8 \%$ for $\delta^{15} \mathrm{~N}$.

\subsection{Gut content analysis}

For gut content analysis, macro- and megafaunal specimens were collected during three Discovery cruises to the PAP site in September 1996 (cruise D222), March 1997 (cruise D226), and July 1997 (cruise D229). Individuals of the more abundant and conspicuous species were preserved in $4 \%$ formaldehyde-seawater solution. Whenever possible, ten individuals of each species on each cruise were examined. The specimens were dissected and their gut contents separated. The total gut contents of smaller animals were analyzed, whereas for larger organisms (e.g. Holothuroidea) a subsample was taken from the foregut. The relative proportions (in terms of volume) of phytodetritus, sediment, and animal remains were determined semiquantitatively.

\section{Results}

Results on stomach content composition of benthic species are summarized in Table 1. In several taxa all the individuals investigated had empty guts. In other taxa no material for analysis of the diet could be obtained. Based on their gut content composition and on lifestyle, the species were classified into feeding types (Table 1). The majority of the macro- and megafaunal taxa investigated proved to be either surface deposit feeders (SDF, $N=26$ ) or subsurface deposit feeders (SSDF, $N=9$ ); a few taxa were identified as either suspension feeders $(\mathrm{SF}, N=17)$ or predators/scavengers $(\mathrm{P} / \mathrm{S}, N=29)$. In most SDF and SSDF the proportion of phytodetritus in the guts was high in September 1996 and low in March and June 1997. Only a few species, such as the ophiuroid Ophiocten hastatum and some holothurian species (Amperima 
K. Iken et al. / Progress in Oceanography 50 (2001) 383-405

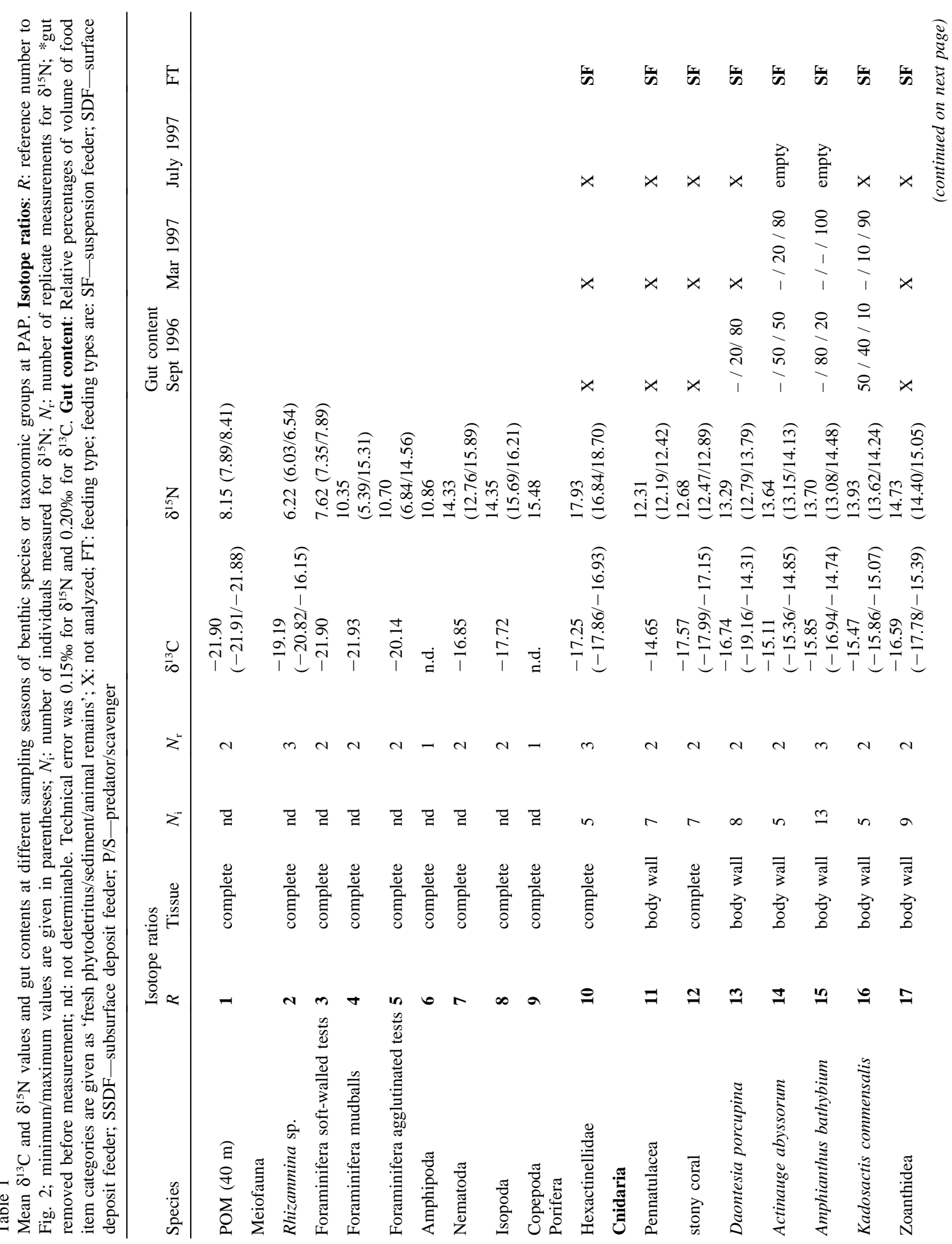




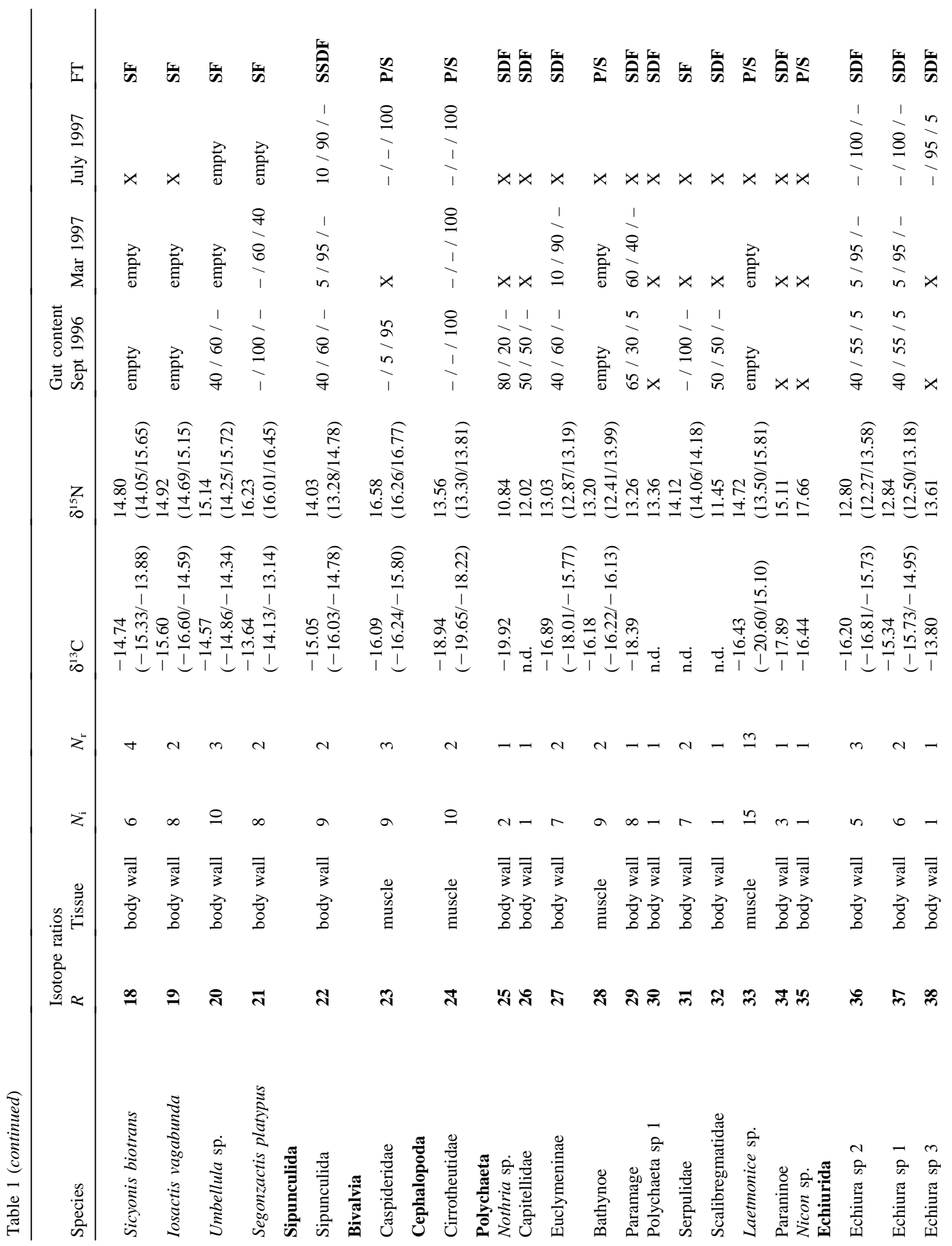




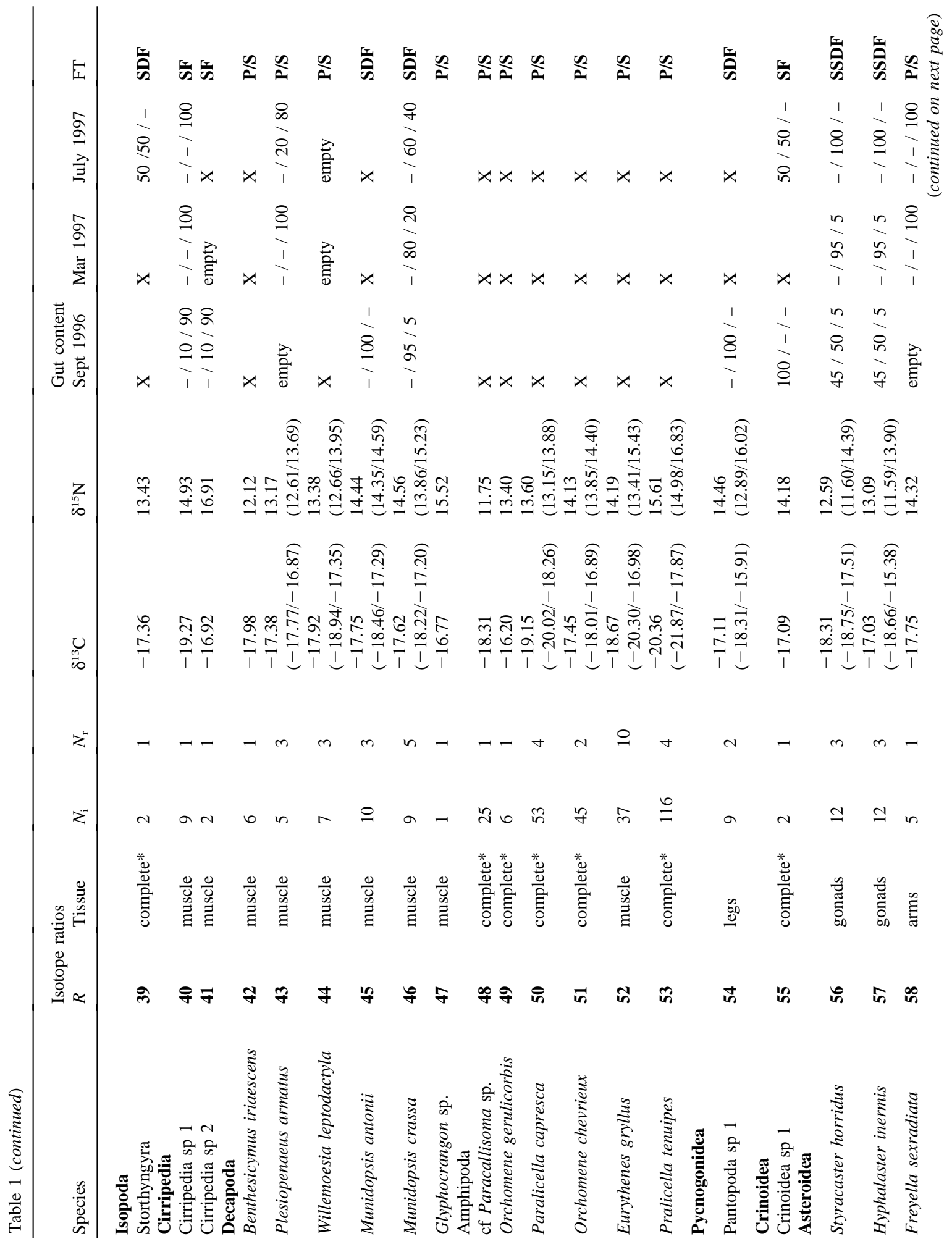




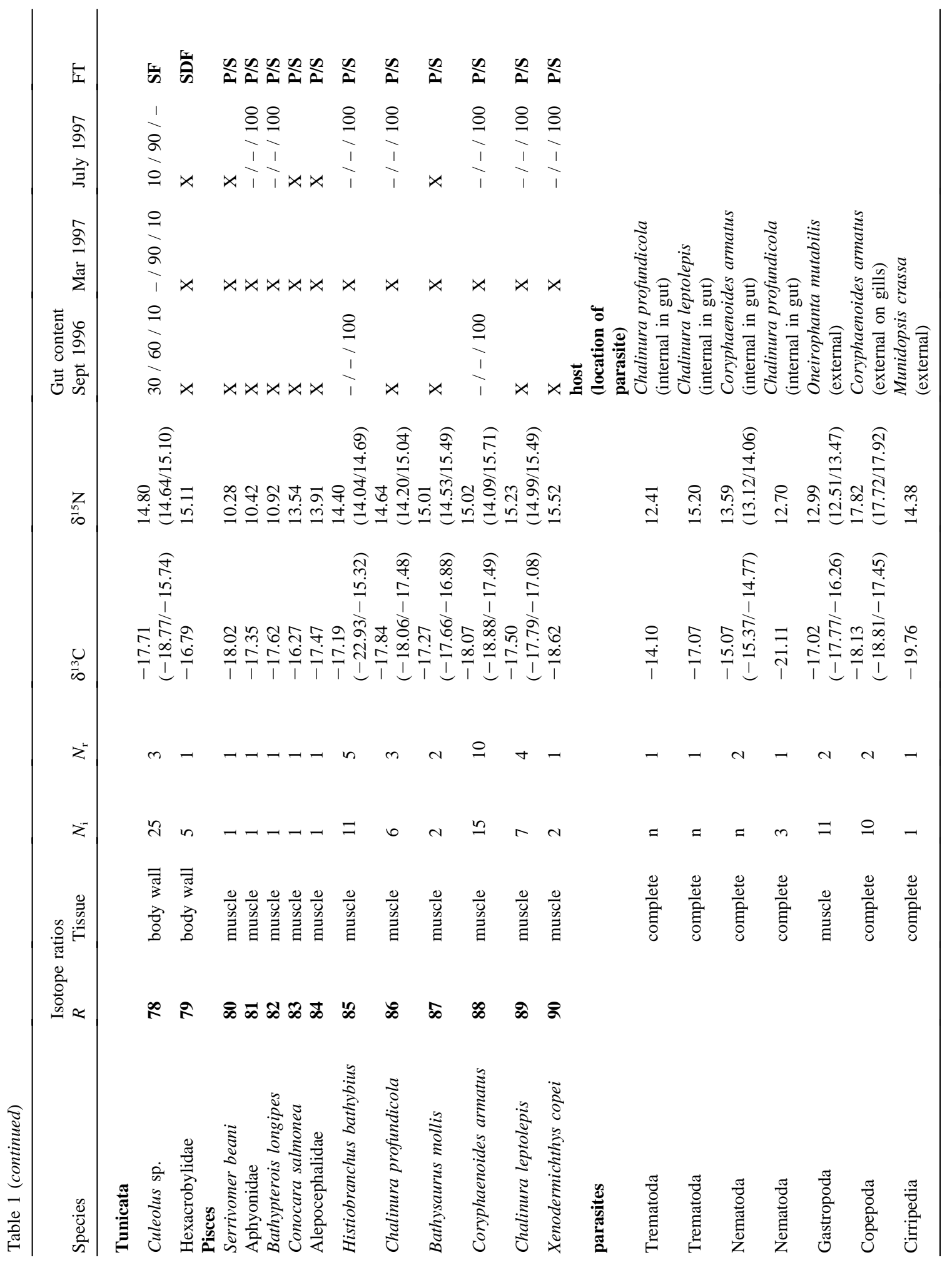


rosea, Ellipinion molle, Peniagone diaphana) were found to have ingested considerable amounts of POM during March and July 1997. Seasonal variability in the dietary composition of predator/scavengers was low.

Ninety taxa (54 species, 32 higher taxonomic groups, and 4 mixed groups) of the benthic community were analyzed for stable carbon and nitrogen isotopes (Table 1). The overall correlation between $\delta^{13} \mathrm{C}$ and $\delta^{15} \mathrm{~N}$ was weak $\left(r^{2}=0.261, N=84\right.$, Fig. 1$)$, indicating a non-linear food web in which $\delta^{13} \mathrm{C}$ is usually a less useful tool for food web analysis (see comments in Section 4.1). Hence we concentrated our study on nitrogen isotopes. $\delta^{15} \mathrm{~N}$ values ranged from $6.22 \%$ in Rhizammina sp. to $17.93 \%$ in a hexactinellid sponge. Thus the components of the food web investigated covered a $\delta^{15} \mathrm{~N}$ range of $>10 \%$, which corresponds to approximately three trophic levels (Fig. 2).

POM had the lowest $\delta^{15} \mathrm{~N}$ value, $8.15 \%$, with the exception of Rhizammina sp. and other soft-walled tested foraminiferans. Distinct differences were detected in $\delta^{15} \mathrm{~N}$ in the meiofaunal groups investigated. Foraminiferans and meiofaunal amphipods had low values which were within a single trophic level of POM, whereas the $\delta^{15} \mathrm{~N}$ of nematodes, isopods and copepods was distinctly higher.

All macro- and megafaunal feeding types showed wide ranges of $\delta^{15} \mathrm{~N}$ values covering about $4 \%$ in SSDF and up to $>7 \%$ in $\mathrm{P} / \mathrm{S}$ (Fig. 3). Mean $\delta^{15} \mathrm{~N}$ was significantly $(P<0.05)$ lower in SDF (mean $\delta^{15} \mathrm{~N}=12.85 \pm 1.32$ ) than in the other three groups (SF: mean $\delta^{15} \mathrm{~N}=14.60 \pm 1.43$; SSDF: mean $\delta^{15} \mathrm{~N}=14.70 \pm 1.41$; P/S: mean $\delta^{15} \mathrm{~N}=14.13 \pm 1.85$ ), using analysis of variance (ANOVA, Shapiro-Wilk test for normal distribution, Levene's test for homogeneity among variances) with Games-Howell's post-hoc test. Some taxa of higher taxonomy groups show narrow ranges of $\delta^{15} \mathrm{~N}$ values (e.g. Cnidaria, Crustacea), whereas the species of other taxa such as Polychaeta, Holothuroidea and Pisces had wider ranges of $\delta^{15} \mathrm{~N}$, up to $6 \%$.

Parasite-host relationships were considered separately (Fig. 4). Cirripedes and gastropods, ectoparasitic on the decapod Munidopsis crassa and the holothurian Oneirophanta mutabilis, respectively, and trematodes living in the hind guts of fish, showed stable nitrogen values similar to their hosts. Whereas nematodes from fish stomachs exhibited distinctly lower values than their hosts, in copepod ectoparasites found on the gills of Coryphaenoides armatus the values were higher than their host.

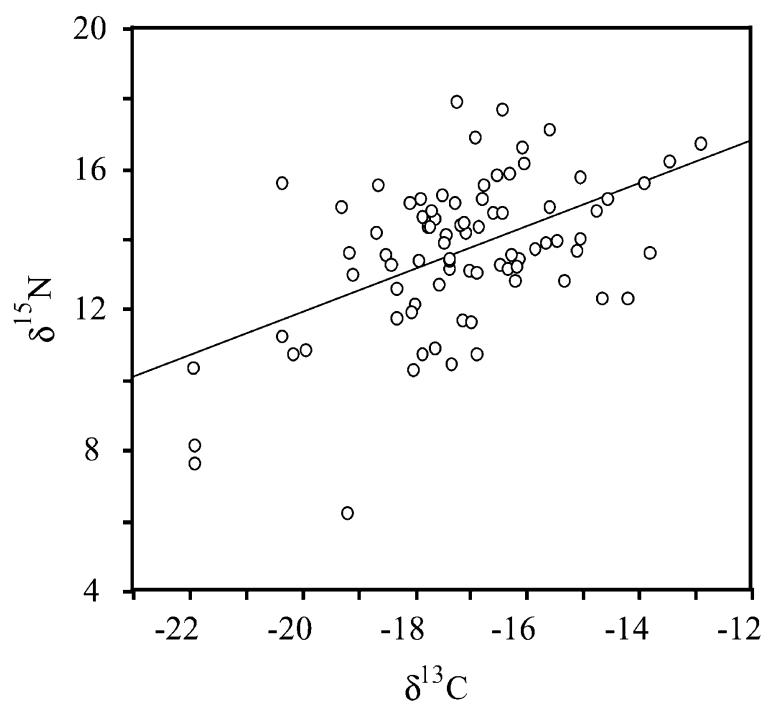

Fig. 1. Relation between $\delta^{13} \mathrm{C}$ and $\delta^{15} \mathrm{~N}$ in all species/groups measured. $\delta^{15} \mathrm{~N}=24.11+0.611 \cdot \delta^{13} \mathrm{C} ; r^{2}=0.261, N=84$. 


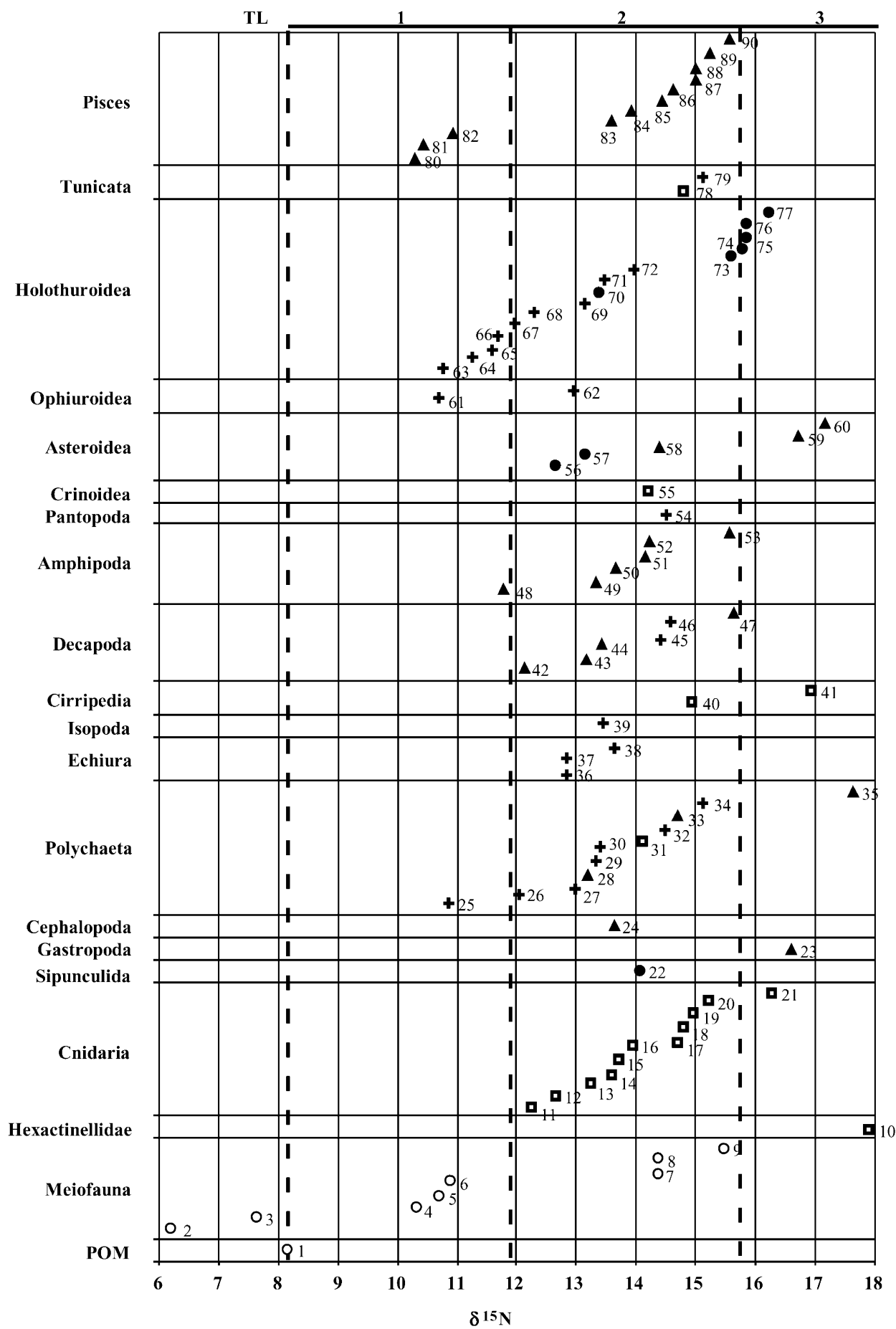

Fig. 2. Relative trophic position of benthic species/groups at PAP based on $\delta^{15} \mathrm{~N}$ (numbers refer to species/groups in Table 1). TL: relative trophic level. Different feeding types are designated with squares (suspension feeders), crosses (surface deposit feeders), filled circles (subsurface deposit feeders), triangles (predator/scavenger), and open circles (no feeding type associated). 


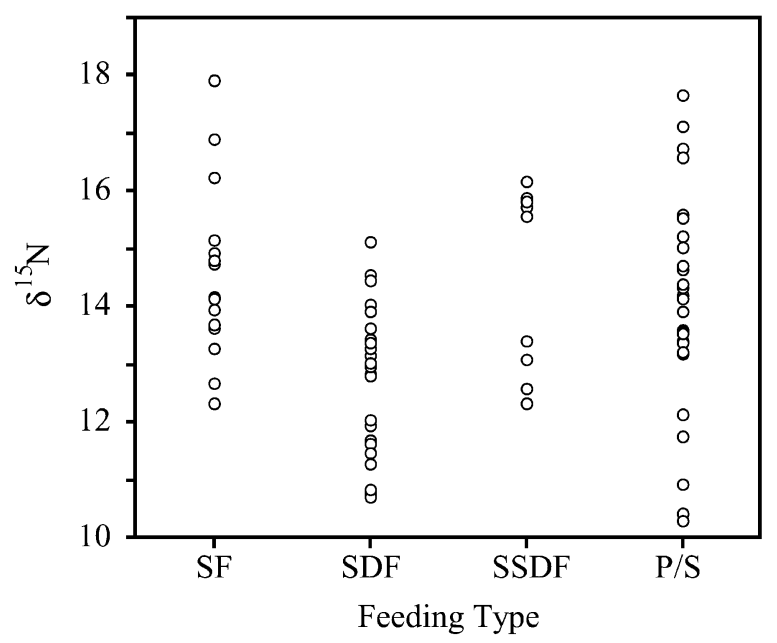

Fig. 3. Distribution of $\delta^{15} \mathrm{~N}$ values among different macro- and megafaunal feeding types. SF: suspension feeders, mean $=14.60 \pm 1.43$; SDF: surface deposit feeders, mean=12.85 \pm 1.32 ; SSDF: subsurface deposit feeders, mean=14.70 \pm 1.41 ; P/S: predators/scavengers, mean $=14.13 \pm 1.85$.

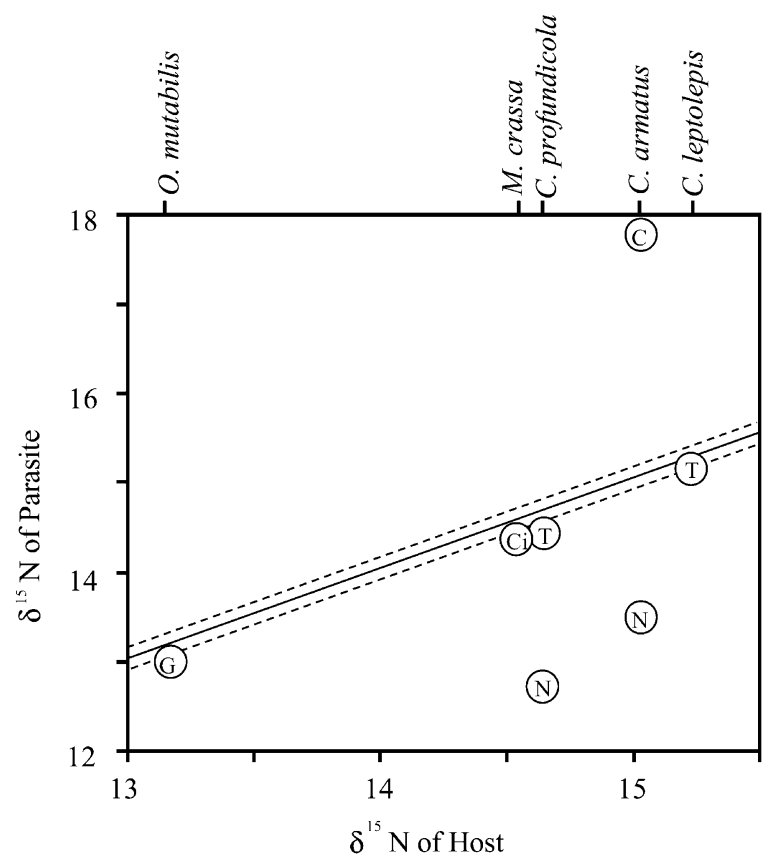

Fig. 4. $\quad \delta^{15} \mathrm{~N}$ relationships between the hosts Oneirophanta mutabilis, Munidopsis crassa, Chalinura profundicola, Chalinura leptolepis, Coryphaenoides armatus and their parasites. Line $\left( \pm 0.15 \%\right.$ technical variation) indicates identical $\delta^{15} \mathrm{~N}$ values of host and parasite. Parasitic groups are: NE: Nematoda; Tr: Trematoda; G: Gastropoda; C: Copepoda; Ci: Cirripedia. 


\section{Discussion}

\subsection{Methodological approach}

Our aim was to analyze the benthic deep-sea food web at PAP and we believe that our sampling was representative of that specific benthic community. Benthic deep-sea communities exhibit natural variability which is reflected in their patchy distribution (e.g. Rice \& Lambshead, 1994; Rice et al., 1994; Thurston et al., 1994; Gooday, 1993; Bett \& Rice, 1992; Billett \& Hansen, 1982). As discussed below, although our sampling of the meiofaunal community was limited, it allowed us to include this group, which is considered to be a significant contributor to energy transfer within the benthic community (e.g. Gooday, Levin, Linke, \& Heeger, 1992). Among the macrofauna, polychaetes are the dominant group in terms of biomass and abundance (Cosson et al., 1997; Gage, Lamont, \& Tyler, 1995; Hessler \& Jumars, 1974), and a large range of species and feeding types has been included here. The megabenthos is well represented in our study and included all the key species of the more important invertebrate groups occurring at this deep-sea site (Holothuroidea, Cnidaria, Asteroidea, Crustacea; Thurston et al., 1994; Billett, 1991), as well as a broad and representative spectrum of demersal fish and benthopelagic amphipods (Thurston, 1990). Several species, which were formerly rare but increased significantly in abundance during the course of the BENGAL project, have been included, such as the holothurians Amperima rosea and Ellipinion molle, as well as several cnidarians (e.g. Iosactis vagabunda).

In recent years, the use of stable isotope ratios as natural tracers in marine food webs has attracted increasing interest (overview in Michener \& Schell, 1994). Initial investigations were based only upon stable carbon isotope ratios, but it became increasingly clear that $\delta^{13} \mathrm{C}$ is biased by the lipid content of the organism being investigated, because rates of ${ }^{13} \mathrm{C}$ enrichment differ between carbohydrates, proteins and lipids (e.g. Wada, Terazaki, Kabaya, \& Nemoto, 1987). $\delta^{13} \mathrm{C}$ can be a good food chain marker when samples are defatted prior to isotope analysis (e.g. Hobson, Ambrose, \& Renaud, 1995; Monteiro, James, Sholto-Douglas, \& Field, 1991). It is very useful for distinguishing food sources at the first trophic level of the food web (e.g. Fry \& Quiñones, 1994; Rau, Heyraud, \& Cherry, 1989), and between organic carbon originating from several primary sources (e.g. Hobson \& Welch, 1992; Dunton \& Schell, 1987; McConnaughey \& McRoy, 1979). It also facilitates the study of chemosynthesis-based ecosystems (e.g. Van Dover \& Fry 1994, 1987; Rau, 1981; Rau \& Hedges, 1979). In our study, however, $\delta^{13} \mathrm{C}$ was of only limited use for the interpretation of trophic relations because the lipids were not extracted, and also the organic carbon at PAP originated mainly from a single source oceanic phytoplankton.

Enrichment of ${ }^{15} \mathrm{~N}$ seems to be more conservative and less variable amongst the biochemical fractions (DeNiro \& Epstein, 1981; Minagawa \& Wada, 1984), and recent investigations have shown that $\delta^{15} \mathrm{~N}$ is a more reliable tool for food web analysis (e.g. Hobson \& Welch, 1992). Moreover, the analysis of stomach contents provides useful additional information on the organism's trophic position and can help in the interpretation of stable isotope ratios, especially in systems either with several major trophic pathways (e.g. Jennings et al., 1997; Cabana \& Rasmussen, 1994; Fry, 1988) or those in which there is intense reworking of the limited food resources (as demonstrated below in this study).

\subsection{Food sources at PAP}

At PAP, annual energy input into the benthic system is concentrated in the short pulse of phytodetritus deposition which reaches the seabed about 4-6 weeks after the bloom develops in the euphotic zone (Rice et al., 1994; Billett et al., 1983). During its vertical transport, POM is subjected to remineralization and degradation which may reduce its nutritive value and affect the isotope ratios in a rather unpredictable way (Rice et al., 1986; Macko \& Estep, 1984). Furthermore, isotopic values usually differ between discrete size classes of POM with smaller particles having lower $\delta^{15} \mathrm{~N}$ values (Rau, Teyssie, Rassoulzadegan, \& 
Fowler, 1990). Clean or size fractionated POM samples are even more difficult to obtain close to the seafloor than from the surface layer. POM arriving at the seabed is a mixture of various components such as phytoplankton, associated microorganisms, amorphous aggregates (marine snow), faecal pellets and moults (Sokolova, 1997; Lampitt, Hillier, \& Challenor, 1993).

Hence, fresh food for suspension feeders (SF) is abundant only during the brief post-bloom period and extremely sparse during the remainder of the year, so for most of the year suspension feeders are dependant on resuspended material (Lampitt, 1985). On the seafloor, fresh POM occurs as greenish fluffy lumps or mats ('fluff') which become mixed with the surficial sediment layer by benthic storms, tidal movement and bioturbation (e.g. Smith, 1992), and these become the principal food source for all surface deposit feeders (SDF). Depending on the amount of sedimented matter, sediment reworking by bioturbation and feeding activity of larger animals incorporates only a relatively small fraction of this material into deeper sediments, making it available to subsurface deposit feeders (SSDF) (Bogdanov, Gurvich, \& Lisitsyn, 1979; Lisitsyn \& Vinogradov, 1982). Predators/scavengers (P/S) may rely on either benthic food sources or, depending on their mobility, on abyssopelagic prey from the benthic boundary layer. Large food falls may feed into a distinct alternative pathway of energy transfer, which bypasses the benthic community (e.g. Gage \& Tyler, 1991; Mahaut, Geistdorfer, \& Sibuet, 1990). Members exploiting this second pathway may be identified by their lower $\delta^{15} \mathrm{~N}$ values, because their prey do not depend on the frequently recycled sedimented POM. Trophic relations within the PAP community may further be complicated by a possible tendency towards vertical extension of trophic niches in various taxa and feeding types, which is currently being being discussed as a typical feature of strongly food limited systems (e.g. Gage \& Tyler, 1991; JarreTeichmann et al., 1997; Sokolova, 1997).

\subsection{Food web structure at PAP}

The dominance of SDF and SSDF taxa (35+ Meiofauna) over SF taxa (17) and P/S taxa (18 benthic invertebrate taxa +11 finfish taxa, see Table 1) implies that sedimented POM is indeed the major food source for the benthic community at PAP. The $\delta^{15} \mathrm{~N}$ data seem to support this view; about two thirds of the measurements were clustered in a range between $12 \%$ and $16 \%$. A closer look at our $\delta^{15} \mathrm{~N}$ data, however, indicates that the food web structure at PAP is not that simple. Comparing the range of $\delta^{15} \mathrm{~N}$ values of the presumable end consumers, fish, with that of benthic invertebrate top predators such as the polychaete Nicon sp. and the asteroid Dytaster grandis, the latter group have higher $\delta^{15} \mathrm{~N}$ values than those of the highly mobile P/S with swimming capability such as fish, amphipods and decapods. This leads to the conclusion that the swimming P/S are largely decoupled from the food web based on sedimented and frequently recycled POM, and most are part of the second pathway of energy transfer, dependant on abyssopelagic prey and large food falls, thus confirming observations of Mahaut et al. (1990), Mauchline and Gordon (1984), and others.

\subsection{The POM dependent benthic food web}

\subsubsection{Meiofauna}

Stable isotope analysis of meiofaunal organisms is of limited value because analyses are based on a mix of species in order to obtain sufficient mass for isotopic analyses and whose protoplasm cannot be separated from the food they contain. Thus any species-specific feeding characteristics will be cancelled so values have to be regarded with some caution. Even so, our results provide some interesting new insights into the feeding strategies of meiofaunal organisms. The meiofauna consists of both metazoans and larger protozoan organisms, are often dominant numerically and in terms of biomass in benthic deep-sea environments and so play a highly important role in energy flow (Gooday et al., 1992; Tietjen, 1992). As components of the food web, they are not only important consumers, but also may serve as an important food 
source either for non-selective deposit feeders (see review in Sokolova, 1997) or for selective consumers of foraminifers (Gooday et al., 1992; Lipps, 1983).

Benthic Foraminifera (foraminifers) are a highly diverse group which, in terms of biomass probably dominate the meiofaunal community at abyssal depths (Gooday, 1986; Snider, Burnett, \& Hessler, 1984). Most individuals and species live in the uppermost sediment layer, but little is known of their feeding ecology (Gooday et al., 1992; Gooday, 1986). A specific assemblage of foraminifers inhabits the phytodetrital lumps and the species are believed to feed on associated microorganisms (Gooday, 1993).

In this study we have distinguished between foraminifers with soft-walled tests (mainly Komokiacea), that form mudballs (Komokiacea with associated sediment), and those with calcareous/agglutinated tests. These three groups show differences in their trophic position. The soft-walled test forams have mean $\delta^{15} \mathrm{~N}$ values lower than those of POM. Those with agglutinated tests or forming mudballs have values consistent with the first trophic level, i.e. close to POM. Whether these differences reflect actual differences in their feeding strategies is difficult to interpret because variability in $\delta^{15} \mathrm{~N}$ values of foraminifers is very high. The foraminifer groups may either feed on different size classes of the available POM, of which the small particles usually exhibit lower $\delta^{15} \mathrm{~N}$ values (Rau et al., 1990), or rely on different microbial food sources. However, most foraminifers are known to store their waste products (stercomes), which may bias their overall isotopic values. The majority of species contain little protoplasm compared to the mass of their tests, which in many cases are not secreted by the organisms but are constructed of material obtained from the environment. Hence $\delta^{15} \mathrm{~N}$ data referring to foraminifers have to be interpreted with care.

Nematodes are considered the most important and numerous metazoan meiofauna group in marine softbottom sediments, and are also abundant in deep ocean sediments (Vincx et al., 1994; Heip, Vincx, \& Vranken, 1985). Their abundance is highest in the top layer of the sediment and decreases rapidly with sediment depth (Snider et al., 1984; Thiel, 1983), suggesting that they depend strongly on the input of fresh POM (Lambshead, Ferrero, \& Wolff, 1995). However, their $\delta^{15} \mathrm{~N}$ values seem too high to reflect feeding on fresh POM, which may be either because of site specific features of nematode ecology and/or to sampling bias. $\delta^{15} \mathrm{~N}$ values of nematodes may also be related to nematode size, because larger nematodes tend to occur deeper within the sediment (Soetaert \& Heip, 1989), where they encounter more degraded material than fresh POM. Those larger nematodes are more abundant at PAP than at other, more oligotrophic sites studied (Vanreusel, Vincx, Bett, \& Rice, 1995). Additionally, our sampling may be biased towards larger individuals or species, which are more likely to be detected without staining. However, similar results have been reported from the analysis of mixed meiofaunal organisms containing ca $98 \%$ nematodes sampled in shallow water sediment from Southeastern Alaska (Goering, Alexander, \& Haubenstock, 1990). Their meiofaunal $\delta^{15} \mathrm{~N}$ values were well above those of most surface deposit feeders and 7.8\% higher than the phytoplankton, indicating that there the nematodes were not depending on POM directly. Carnivory or feeding on nanobiota such as bacteria or fungi were considered as alternative feeding strategies (Goering et al., 1990).

\subsubsection{Macro- and megafauna}

Macro- and megafaunal feeding types not only showed a large range of $\delta^{15} \mathrm{~N}$ values, but also showed strong overlap in food sources. Competition for food is generally thought to exert strong evolutionary pressure that drives trophic niche separation, either by specialization (Roberts \& Moore, 1997; Billett, Llewellyn, \& Watson, 1988) and/or by vertical expansion of trophic niches, i.e. omnivory (Gage \& Tyler, 1991; Jarre-Teichmann et al., 1997; Sokolova, 1997).

The feeding strategies of suspension feeders (SF) are assumed to be closely coupled to the seasonal input of POM. However, because of the restricted availability of fresh POM, deep-sea SF have expanded the spectrum of the food they utilize to include resuspended material (Lampitt, 1985). Hence in the deep ocean SF compete directly with the deposit feeders (SDF and SSDF) for the limited POM food source, intensifying the trophic competition. Even so, our study reveals some examples of trophic niche separation 
in SF taxa: Pennatulacea (sea pens) are basically microphagous SF. The $\delta^{15} \mathrm{~N}$ of the large Umbellula sp. $\left(>50 \mathrm{~cm}\right.$ height at PAP) is distinctly higher $\left(15.14 \%\right.$ ) than $\delta^{15} \mathrm{~N}$ of the second, much smaller Pennatulacea (12.31\%o, nos. 20 and 11 in Fig. 2, respectively), indicating that Umbellula sp. feeds at higher trophic levels, e.g. by macrophagy as assumed by Gage and Tyler (1991). Another example is the (yet unidentified) hexactinellid sponge, which shows the highest $\delta^{15} \mathrm{~N}(17.93 \%$ ) of all taxa investigated. Interestingly, similar high $\delta^{15} \mathrm{~N}$ values have been found in sponges from the Arctic (Iken, unpublished data). These sponges do not seem to be closely coupled to the sedimenting POM but depend on other food sources with distinctly higher $\delta^{15} \mathrm{~N}$ values; possible sources may be symbiotic bacteria, which play an important role in the nutrition of some shallow waters sponges (Arillo, Bavestrello, Burlando, \& Sara, 1993; Reiswig, 1975). Those bacteria may be able to metabolize highly refractory material, which can then be assimilated by the sponge. Another strategy may be macrophagy on small swimming organisms, as observed in sponges living in shallow water caves (Vacelet \& Boury-Esnault, 1995).

As stated above, macro- and megabenthic deposit feeders (35 taxa) dominate the community at PAP. The significant difference $(P<0.05)$ in $\delta^{15} \mathrm{~N}$ values between SDF (mean $\left.\delta^{15} \mathrm{~N}=12.85 \% \pm \pm 1.32\right)$ and SSDF (mean $\delta^{15} \mathrm{~N}=14.70 \% \pm \pm 1.41$ ) indicates that the latter feed on more refractory and recycled material. This makes sense, as POM will be metabolized partially while being worked into the sediment (Conte, Madureira, Eglinton, Keen, \& Rendall, 1994; Santos, Billett, Rice, \& Wolff, 1994). Nevertheless, the wide range of $\delta^{15} \mathrm{~N}$ values within the two feeding groups (SDF: 10.7-15.11\%o; SSDF 12.59-16.18\%o, see Fig. 3) indicates further trophic niches separation with respect to the 'recycling status' of the diet. Spatial and temporal variability of food quality and quantity is the lever available for the evolutionary development towards distinct trophic niches within the deposit feeders. This spatio-temporal patchwork is created by seasonality of sedimentation, local resuspension by interaction of bottom currents and bottom topography (Lampitt, 1985; Billett et al., 1983), spatial heterogeneity in activity of micro- and meiofauna (Patching \& Eardly, 1997; Gooday \& Turley, 1990), and the constant albeit patchy bioturbation and recycling by macroand megafaunal organisms themselves. Below, we discuss this separation of trophic niches among holothurians and a few other taxa.

Holothurians are the dominant megabenthic group in terms of biomass and abundance at PAP (Thurston et al., 1994; Billett, 1991). Three trophic groups can be identified according to their $\delta^{15} \mathrm{~N}$ values (group A: 10.75-12.33\%o, group B: 13.16-13.92\%o, group C: 15.58-16.18\%o, see Fig. 2). Regarding holothurian morphology, resource partitioning is mainly discussed in terms of tentacle structure (Roberts, 1979; Roberts \& Bryce, 1982; Klinger, Johnson, \& Jell, 1994; Roberts \& Moore, 1997). Different morphological types of tentacle have been proposed to account either for differences in particle size selection (Roberts, 1979) or for selection of organically enriched particles (Khripounoff \& Sibuet, 1980; Billett et al., 1988). Selective feeding in holothurians, however, is still a matter of debate. At present neither tentacle ultrastructure and morphological classification nor particle selection by adhesion are sufficiently understood to allow discrimination of holothurian feeding types based on tentacle characteristics alone (e.g. Lawrence, 1987; McKenzie, 1984; Moore \& Roberts, 1994; Roberts \& Moore, 1997). The three trophic groups identified in our study do not show distinctive characteristics in their tentacle shape and ultrastructure. Digitate and peltate forms are the dominant types in all three groups, although the long, narrow, sometimes shield-like tentacles (Lawrence, 1987) of the Molpadida (Molpadia blakei) are confined to group C.

We suggest that a combination of factors, such as morphology (tentacle structure, body wall consistency, body extensions), mobility (buoyancy, swimming capability), and digestive properties (enzymatic activities, enteric bacteria) has to be considered to explain holothurian niche separation at PAP.

Billett (1991) recognised five strategies in deposit feeding by deep-sea holothurians. According to his system of trophic strategies, most members of our group A would be classified either as pelagic superficial sediment feeders (Peniagone diaphana) or as mobile superficial sediment feeders (Amperima rosea, Ellipinion molle). The feature common to all these species is the gelatinous structure of the body wall that gives them near neutral buoyancy; this together with their small body size (mean body mass between 3 and 
$11 \mathrm{~g}$ wet weight; data courtesy Bett and Thurston, SOC) means they are readily carried into suspension by bottom-near currents; their distinct velum may give them a measure of control over their direction of drift. P. diaphana is a benthopelagic species occurring up to 70 mab (Billett, 1991; Barnes, Quetin, Childress, \& Pawson, 1976) and has been reported to feed both pelagically as well as benthically (Billett, 1986; Billett, Hansen, \& Huggett, 1984; Barnes et al., 1976). The low $\delta^{15} \mathrm{~N}$ values (range 10.75-12.33\%o) of these species indicate that they feed on fresh POM, and the isotopic data are confirmed by gut content analysis. These species contained considerable amounts of phytodetritus in their guts during all sampling seasons, even in July 1997, when no deposition to the PAP benthic system was apparent in the Bathysnap observations. Obviously, their high mobility enables A. rosea, Ellipinion molle, and P. diaphana to locate efficiently and exploit patchily distributed phytodetrital lumps. In general terms, species of group A appear to be investing comparatively more energy in foraging for food of comparatively high nutritional value. This strategy appears to be effective at PAP since A. rosea was the most abundant megafaunal species at PAP during BENGAL. From the Bathysnap observations, its abundance reached up to 6000 ind. hectare $^{-1}$ (Billett et al., 2001).

Holothurian group B is comprised of larger species such as Oneirophanta mutabilis, Deima validum, and Psychropotes longicauda, whose average body mass ranged between 32 and $600 \mathrm{~g}$ wet weight (data courtesy Bett and Thurston, SOC). These are mobile superficial sediment feeders (Billett, 1991), which sweep and rake the surficial sediment layers with their tentacles into the ventrally located mouth, similar to species of group A (Roberts \& Moore, 1997; Moore \& Roberts, 1994; Hansen, 1975). However, their $\delta^{15} \mathrm{~N}$ values (range 13.16-13.92\%o) indicate that the species of group B are feeding on older, more recycled organic matter than those of group A. This is most likely related to differences in the mobility of the species in the two groups. Only P. longicauda, which is pelagic as a juvenile (Tyler \& Billett, 1987), is known to have limited swimming abilities as a result of its gelatinous body and long 'tail' (Pawson, 1985). The body walls of the other species are less gelatinous, and so have limited, if any, swimming capability. Hence, species of group B have less capability for searching patches of fresh phytodetritus than those of group A. Recent studies of the digestive systems of $O$. mutabilis and $P$. longicauda have revealed they have highly developed enzymatic capacities as well as a bacterial flora, which plays an important role in enabling them to break down more refractory material (Moore \& Roberts, 1994; Roberts et al., 2001).

All species of holothurian group C are classified as SSDF (Table 1) or, according to Billett (1991), as sedentary or infaunal sediment feeders. Their average body mass ranges from 47 to $365 \mathrm{~g}$ wet weight (data courtesy Bett and Thurston, SOC). Species like Molpadia blakei or Pseudostichopus villosus are equipped for a largely stationary, ploughing or burrowing lifestyle. They have a 'sausage-shaped' body form, they lack distinct tube feet and any kind of body extensions such as a velum or tail, which may aid movement or buoyancy. Their body walls are not gelatinous so they are not expected to have any swimming capability. The long, narrow, sometimes shield-like tentacles of $M$. blakei function to shovel large amounts of sediment into the apical mouth (Lawrence, 1987). The enzymatic characteristic of the gut contents of the species in group $\mathrm{C}$ indicate they are capable of breaking down bacterial membranes, and their enteric bacteria may break down refractory compounds, which can then be utilized by the holothurians (Roberts et al., 2001). Their high $\delta^{15} \mathrm{~N}$ values (15.58-16.18\%o) confirm that these species are specialists in exploiting the refractory or frequently recycled organic matter of low nutritional value, that is encountered in sub-surface sediments. They invest very little energy in foraging and so are comparatively decoupled from seasonally limited sedimentation events.

Expansion of the trophic spectrum through the evaluation of increased mobility is seen in cnidarians, a primarily sessile group. Most benthic cnidarians are considered to be opportunistic omnivores, containing high proportions of sediment and animal prey (mainly polychaetes and crustaceans) in their guts (Table 1). Morphologically the two species studied, Kadosactis commensalis and Segonzactis platypus, are nearly identical, but differ considerably in their life style as well as in their relative position in the food web. $K$. commensalis lives commensally on holothurians, predominantly on Paroriza prouhoi and, less frequently, 
on Pseudostichopus villosus. Its $\delta^{15} \mathrm{~N}$ value $(13.93 \%$ ) is close to the values of its hosts, indicating primarily commensal feeding on fine particles resuspended by the activity of the hosting holothurian. S. platypus, on the other hand, is a free living, mobile species which can actively seek food and may be considered more predatory $\left(\delta^{15} \mathrm{~N}=16.23 \%\right.$ ). A recently described hemisessile species Iosactis vagabunda (RiemannZürneck, 1997) seems to occupy an intermediate trophic position $\left(\delta^{15} \mathrm{~N}=14.92 \%\right.$ ). The three species demonstrate a trend for increasing mobility leading to an increasingly carnivorous diet, i.e. vertical trophic niche expansion.

Trophic separation is also detectable in our data between the two ophiuroids, Ophiomusium lymani $\left(\delta^{15} \mathrm{~N}=12.97 \%\right.$ ) and Ophiocten hastatum $\left(\delta^{15} \mathrm{~N}=10.70 \%\right.$ ) . The latter feeds nearly exclusively on fresh POM, whereas the trophic spectrum of $O$. lymani is extended towards facultative predation on small crustaceans and polychaetes (Table 1). Similar to the holothurians Amperima rosea and Ellipinion molle (see above), Ophiocten hastatum seems to be very efficient in tracing fresh phytodetritus even in times of low deposition rates.

Top predators in the benthic food web $\left(\delta^{15} \mathrm{~N}\right.$ range $=16.58-17.66 \%$ ) are mainly polychaetes and asteroids (see Section 4.3). Their very high $\delta^{15} \mathrm{~N}$ values reflect extensive feeding on benthic deposit feeders, prey which depend on frequently recycled POM.

\subsection{The benthopelagic food web}

The deep-sea bottom is closely related hydrographically and biologically to the overlying water column by the benthic boundary layer (BBL), which may extend up to 100 mab (Smith \& Hinga, 1983). In the abyssal BBL pelagic organisms accumulate because of their biological interactions with the sediment (Angel, 1990) and hence become accessible prey for mobile benthopelagic species able to migrate into the overlying water layer for feeding. As discussed above, the highly mobile predators/scavengers (P/S) with swimming capability such as fish, amphipods and decapods encountered at PAP may be decoupled to various degrees from the benthic food web which depends on sedimented POM. Competition for food is considered to be high among the $\mathrm{P} / \mathrm{S}$ fauna because of low prey availability and spatial and the temporal unpredictability of large food falls. The wide range of $\delta^{15} \mathrm{~N}$ values in these benthopelagic P/S (10.28$15.61 \%$ ) indicates there is a degree of trophic niche separation within this feeding type. Our $\delta^{15} \mathrm{~N}$ data combined with the available information on lifestyles separates the benthopelagic P/S into two groups. One group consists of benthopelagic P/S which specialize on small pelagic prey and with very low $\delta^{15} \mathrm{~N}$ values (10.28-12.12\%o), such as the fish species Serrivomer beani, Bathypterois longipes and the Aphyonidae. Some Aphyonidae are reported to be abyssopelagic whereas the conspicuous tripod fish B. longipes has a sit-and-wait strategy (Whitehead, Bauchot, Hureau, Nielsen, \& Tortonese, 1986). Sitting on its elongated fin rays this species is extremely sensitive to movements of its swimming prey (e.g. small fish or swimming invertebrates) (Gage \& Tyler, 1991). Within the decapods, the penaeid Benthesicymus iridescens $\left(\delta^{15} \mathrm{~N}=12.12 \%\right.$ ) predominantly feeds on pelagic prey, and the $\delta^{15} \mathrm{~N}$ value $(11.75 \%$ o of the amphipod cf. Paracallisoma sp. indicates it has a similar feeding strategy. Predation as an alternative feeding mode to scavenging in abyssobenthopelagic amphipods is mentioned by Thurston (1990).

The second group includes mobile benthopelagic P/S species which seem to be more or less opportunistic feeders. This group comprises the cirrotheuthid cephalopod $\left(\delta^{15} \mathrm{~N}=13.56 \%\right.$ ), which feeds on a mixed diet of benthic and pelagic prey (isopods/polychaetes and copepods, respectively), scavengers, such as the rattail Coryphaenoides (Nematonurus) armatus and the deep-sea eel Histiobranchus bathybius, and many amphipod species. The $\delta^{15} \mathrm{~N}$ values $(13.17-15.61 \%$ ) of this second group are high, but are still lower than those of true benthic predators $\left(\delta^{15} N=16.58-17.66 \%\right.$, see Section 4.3$)$, indicating that they may form a link between the benthic and benthopelagic trophic pathways. 


\subsection{Parasite-host relationships}

The trophic relationship between parasites and their hosts has to be regarded as a special case within the general food web. We would expect parasites living in the intestines of the host to have similar isotopic values to their host, assuming they feed on the same items as the host does. However, parasites feeding on body tissue or fluids of their host are expected to have stable isotope ratios higher than their hosts.

Trematodes living in the intestines of fishes of the genus Chalinura fit well into this concept (Fig. 4), but nematodes from the stomach of Coryphaenoides armatus and Chalinura profundicola had remarkably lower $\delta^{15} \mathrm{~N}$ values than their respective host. This is probably related to the different locations of these intestinal parasites in the gut: the trematodes mainly inhabit the hind part of the intestine, behind the stomach where the food passing through has already been enzymatically processed by the fish, so host and parasite will assimilate identical material. Nematodes inhabiting the stomachs of their hosts are using the food before it is purged into the intestine of the host. Hence the isotope ratios of the nematodes and the host fish will differ either as a result of specific enzymatic properties or selective feeding of the parasite on the available food.

The ectoparasitic gastropod living on Oneirophanta mutabilis inserts a long siphon into the hosting holothurian. The nearly identical trophic position of host and parasite suggest that the gastropod is inserting its siphon into the gut system feeding on pre-digested food rather than into the coelom of the holothurian. The same applies to the ectoparasitic cirriped species living on Munidopsis crassa, where $\delta^{15} \mathrm{~N}$ value is similar to its host.

Copepods living ectoparasitically on the gills of Coryphaenoides armatus show a $\delta^{15} \mathrm{~N}$ enrichment of about 3\%o with respect to their host, confirming that the copepods are feeding on the blood of the host. This trophic enrichment factor gives strong evidence that isotope fractionation patterns in the deep sea are similar to those in shallow waters, an important observation given the differences in enzyme activities with depth.

\section{Conclusions}

Stable isotope analysis of the benthic food web at PAP revealed a complex system with specific adaptations to the limited food sources. We have been able to identify two distinct albeit overlapping trophic pathways at PAP, a benthic food web depending on sedimenting and recycled POM and a benthopelagic food web depending on abyssopelagic food sources. The majority of deposit feeding taxa were exclusively members of the benthic food web. Among these, competition for food is minimised mainly by specialization on specific POM fractions of different particle ages (i.e. recycling stage) and locality, as shown for holothurians. Highly mobile carnivores with swimming capability constitute the benthopelagic food web at PAP. There are major links between the benthic and the benthopelagic food web: 1) through benthic species showing vertical trophic niche expansion (e.g. cnidarians); and 2) through predators feeding on pelagic as well as on benthic prey (e.g. some fish and crustaceans).

In a food limited system trophic specialisation is a necessary evolutionary development if competing species are to coexist. One attempt to explain evolutionary processes is the 'Stability-Time Hypothesis' of Sanders (1968), which predicts that physical stability of the deep-sea environment allowed evolutionary adaptations within a benthic community in terms of resource partitioning. Diversification of feeding strategies as a result of resource partitioning will also minimize competitive interactions. Within the benthic community at PAP resource partitioning is most striking in the large and diverse group of holothurians (Roberts \& Moore, 1997). At this deep-sea site, the seasonally pulsed inputs of POM into the benthic system can be considered a specific process that favours specialization of feeding strategies. According to the Stability-Time Hypothesis, even higher degrees of trophic specialisation will evolve at more 
oligotrophic deep-sea sites because of the less rich but more predictable food sources. Further stable isotope analyses of the food web at less eutrophic deep-sea locations will be needed to answer this question.

\section{Acknowledgements}

This study was part of the European Commission's Marine Science and Technology Program (MAST III) 'High resolution temporal and spatial study of the benthic biology and geochemistry of a north-eastern Atlantic abyssal locality' (BENGAL), under contract MAS3-CT950018. As typical for such a joint project, our study would not have been possible without the help of all our colleagues: We are grateful to A. Rice and B. Bett, our scientific colleagues, and the crew of RRS Discovery for smooth and satisfying cruises. Special thanks are due to M. Thurston, A. Gooday and D. Billett for their continuous support in species determination and discussions on the biology of deep-sea organisms. Thanks to B. Hilbig for the identification of polychaetes. K. Beyer and L. Schönicke helped with the preparation of samples for isotope analysis. Last but not least, we want to acknowledge the support of P. Talbot who made our administrative life as agreeable and easy as possible. This is AWI publication number 1675.

\section{References}

Angel, M. V. (1990). Life in the benthic boundary layer: connections to the mid-water and sea floor. Philosophical Transactions of the Royal Society, London, 331, 15-28.

Arillo, A., Bavestrello, G., Burlando, B., \& Sara, M. (1993). Metabolic integration between symbiotic cyanobacteria and sponges: a possible mechanism. Marine Biology, 117, 159-162.

Barnes, A. T., Quetin, L. B., Childress, J. J., \& Pawson, D. L. (1976). Deep-sea macroplanctic sea cucumbers: suspended sediment feeders captured from deep submergence vehicle. Science, 194, 1083-1085.

Bett, B. J., \& Rice, A. L. (1992). The influence of hexactinellid sponge (Pheronema carpenteri) spicules on the patchy distribution of macrobenthos in the Porcupine Seabight (bathyal NE Atlantic). Ophelia, 36, 217-226.

Billett, D. S. M. (1986). The rise and rise of the sea-cucumber. New Scientist, 109 (1500), 48-51.

Billett, D. S. M. (1991). Deep-sea holothurians. Oceanography and Marine Biology: an Annual Review, 29, $259-317$.

Billett, D. S. M., Bett, B. J., Rice, A. L., Thurston, M. H., Galéron, J., Sibuet, M., \& Wolff, G. A. (2001). Long-term changes in the megabenthos of the Porcupine Abyssal Plain (NE Atlantic). Progress in Oceanography, 50, 325-348.

Billett, D. S. M., \& Hansen, B. (1982). Abyssal aggregations of Kolga hyalina Danielssen and Koren (Echinodermata: Holothuroidea) in the northeast Atlantic ocean, a preliminary report. Deep-Sea Research, 29A, 799-818.

Billett, D. S. M., Hansen, B., \& Huggett, Q. J. (1984). Pelagic Holothuroidea (Echinodermata) of the northeast Atlantic. In B. F. Keegan, \& B. D. S. O'Connor (Eds.), Proceedings of the $5^{\text {th }}$ international echinoderm conference, Galway (pp. 399-411). Rotterdam: Balkema.

Billett, D. S. M., Lampitt, R. S., Rice, A. L., \& Mantoura, R. F. C. (1983). Seasonal sedimentation of phytoplankton to the deepsea benthos. Nature, London, 302, 520-522.

Billett, D. S. M., Llewellyn, C., \& Watson, J. (1988). Are deep-sea holothurians selective feeders? In R. D. Burke, P. V. Mladenov, P. Lambert, \& R. L. Parsley, Echinoderm biology (pp. 421-429). Rotterdam: Balkema.

Billett, D. S. M., \& Rice, A. L. (2001) The BENGAL programme: introduction and overview. Progress in Oceanography, $50,13-25$.

Bogdanov, Y. A., Gurvich, E. G., \& Lisitsyn, A. P. (1979). A model for the accumulation of organic carbon in the benthic sediments of the pacific ocean (in Russian). Geokhimica, 1, 918-927.

Cabana, G., \& Rasmussen, J. B. (1994). Modelling food chain structure and contaminant bioaccumulation using stable nitrogen isotopes. Nature, London, 372, 255-257.

Conte, M. H., Madureira, L. A. S., Eglinton, G., Keen, D., \& Rendall, C. (1994). Millimeter-scale profiling of abyssal marine sediments: role of bioturbation in early sterol diagenesis. Organic Geochemistry, 22, 979-990.

Cosson, N., Sibuet, M., \& Galéron, J. (1997). Community structure and spatial heterogeneity of the deep-sea macrofauna at three contrasting stations in the northeast Atlantic. Deep-Sea Research I, 44, 247-269.

DeNiro, M. J., \& Epstein, S. (1978). Influence of diet on the distribution of carbon isotopes in animals. Geochimica et Cosmochimica Acta, 42, 495-506.

DeNiro, M. J., \& Epstein, S. (1981). Influence of diet on the distribution of nitrogen isotopes in animals. Geochimica et Cosmochimica Acta, 45, 341-351. 
Dunton, K. H., \& Schell, D. M. (1987). Dependence of consumers on macroalgal (Laminaria solidungula) carbon in an arctic kelp community: $\delta^{13} \mathrm{C}$ evidence. Marine Biology, 93, 615-625.

Fowler, S. W., \& Knauer, G. A. (1986). Role of large particles in the transport of elements and organic compounds through the oceanic water column. Progress in Oceanography, 16, 147-194.

Fry, B. (1988). Food web structure on Georges Bank from stable C, N and S isotopic compositions. Limnology and Oceanography, $33,1182-1190$.

Fry, B., Brand, W., Mersch, F. J., Tholke, K., \& Garritt, R. (1992). Automated analysis system for coupled $\delta^{13} \mathrm{C}$ and $\delta^{15} \mathrm{~N}$ measurements. Analytical Chemistry, 64, 288-291.

Fry, B., \& Sherr, E. B. (1988). $\delta^{13} \mathrm{C}$ measurements as indicators of carbon flow in marine and freshwater ecosystems. In P. W. Rundel, J. R. Ehleringer, \& K. A. Nagy, Stable isotopes in ecological research (pp. 196-229). New York: Springer Verlag.

Fry, B., \& Quiñones, R. B. (1994). Biomass spectra and stable isotope indicators of trophic level in zooplankton of the northwest Atlantic. Marine Ecology Progress Series, 112, 201-204.

Gage, J. D., Lamont, P. A., \& Tyler, P. A. (1995). Deep-sea macrobenthic community at contrasting sites off Portugal, preliminary results: I. Introduction and diversity comparisons. Internationale Revue der gesamten Hydrobiologie, 80, $235-250$.

Gage, J. D., \& Tyler, P. A. (1991). Deep-sea biology: a natural history of organisms at the deep-sea floor. New York: Cambridge University Press.

Goering, J., Alexander, V., \& Haubenstock, N. (1990). Seasonal variability of stable carbon and nitrogen isotope ratios of organisms in a north Pacific bay. Estuarine, Coastal and Shelf Science, 30, 239-260.

Gooday, A. J. (1986). Meiofaunal foraminiferans from the bathyal Porcupine Seabight: size structure, taxonomic composition, species diversity and vertical distribution in the sediment. Deep-Sea Research, 33, 1345-1373.

Gooday, A. J. (1988). A response by benthic Foraminifera to the deposition of phytodetritus in the deep-sea. Nature, 332, 70-73.

Gooday, A. J. (1993). Deep-sea foraminiferal species which exploit phytodetritus: characteristic features and controls on distribution. Marine Micropaleontology, 22, 187-205.

Gooday, A. J., Levin, L. A., Linke, P., \& Heeger, H. (1992). The role of benthic Foraminifera in deep-sea food webs and carbon cycling. In G. T. Rowe, \& V. Pariente, Deep-sea food chains and the global carbon cycle (pp. 63-91). Dordrecht: Kluwer Academic Publishers.

Gooday, A. J., \& Turley, C. M. (1990). Responses by benthic organisms to inputs of organic material to the ocean floor: a review. Philosophical Transactions of the Royal Society of London A, 331, 119-138.

Grassle, J. F., Maciolek, N. J., \& Blake, J. A. (1990). Are deep-sea communities resilient? In G. M. Woodwell, The earth in transition: patterns and processes of biotic impoverishment (pp. 384-459). New York: Cambridge University Press.

Hansen, B. (1975). Systematics and biology of the deep-sea holothurians. Part I. Elasipoda. Galathea Reports, 2 , 55-59.

Heip, C., Vincx, M., \& Vranken, G. (1985). The ecology of marine nematodes. Oceanography and Marine Biology: an Annual Review, 23, 399-489.

Hessler, R. R., \& Jumars, P. A. (1974). Abyssal community analysis from replicate box cores in the central north pacific. Deep-Sea Research, 21, 185-209.

Hobson, K. A., Ambrose, W. G. Jr., \& Renaud, P. E. (1995). Sources of primary production, benthic-pelagic coupling, and trophic relationships within the Northeast Water Polynya: insights from $\delta 13 \mathrm{C}$ and $\delta 15 \mathrm{~N}$ analysis. Marine Ecological Progress Series, $128,1-10$.

Hobson, K. A., \& Welch, H. E. (1992). Determination of trophic relationships within a high Arctic marine food web using $\delta^{13} \mathrm{C}$ and $\delta^{15} \mathrm{~N}$ analysis. Marine Ecological Progress Series, 84, 9-18.

Jarre-Teichmann, A., Brey, T., Bathmann, U. V., Dahm, C., Dieckmann, G. S., Gorny, M., Pagès, F., Plötz, J., Schnack-Schiel, S., Stiller, M., \& Arntz, W. E. (1997). Trophic flows in the benthic shelf community of the eastern Weddell Sea. In B. Battaglia, J. Valencia, \& D. W. H. Walton, Antarctic communities-species, structure and survival (pp. 118-134). New York: Cambridge University Press.

Jennings, S., Reñones, O., Morales-Nin, B., Polunin, N. V. C., Moranta, J., \& Coll, J. (1997). Spatial variation in the ${ }^{15} \mathrm{~N}$ and ${ }^{13} \mathrm{C}$ stable isotope composition of plants, invertebrates and fishes on mediterranean reefs: implications for the study of trophic pathways. Marine Ecology Progress Series, 146, 109-116.

Klinger, T. S., Johnson, C. R., \& Jell, J. (1994). Sediment utilization, feeding-niche breadth and feeding-niche overlap of Aspidochirotida (Echinodermata: Holothuroidea) at Heron Island, Great Barrier Reef. In B. David, \& J.-P. Guille, Echinoderms through time (pp. 523-528). Rotterdam: Balkema.

Khripounoff, A., \& Sibuet, M. (1980). La nutrition d'échinodermes abyssaux I. alimentation des holothuries. Marine Biology, 60, $17-26$.

Lambshead, P. J. D., Ferrero, T. J., \& Wolff, G. A. (1995). Comparison of the vertical distribution of nematodes from two contrasting abyssal sites in the Northeast Atlantic subject to different seasonal inputs of phytodetritus. Internationale Revue der gesamten Hydrobiologie, 80, 327-331.

Lampitt, R. S. (1985). Evidence for the seasonal deposition of detritus to the deep-sea floor and its subsequent resuspension. DeepSea Research, 32, 885-897. 
Lampitt, R. S., Hillier, W. R., \& Challenor, P. G. (1993). Seasonal and dial variation in the open ocean concentration of marine snow aggregates. Nature, London, 362, 737-739.

Lawrence, J. M. (1987). A functional biology of echinoderms. Baltimore: The Johns Hopkins University Press.

Lipps, J. H. (1983). Biotic interrelations in benthic Foraminifera. In M. J. S. Tevesz, \& P. L. McCall, Biotic interaction in recent and fossil benthic communities (pp. 331-376). New York: Plenum Press.

Lisitsyn, A. P., \& Vinogradov, M. E. (1982). Global patterns of distribution of life in the ocean and their reflection in the composition of benthic sediments (in Russian). Izvestia Akademii Nauk SSSR, Seriya Geologicheskaya, 4, 5-24.

Macko, S. A., \& Estep, M. L. F. (1984). Microbial alteration of stable nitrogen and carbon isotopic compositions of organic matter. Organic Geochemistry, 6, 787-790.

Mahaut, M.-L., Geistdorfer, P., \& Sibuet, M. (1990). Trophic strategies in carnivorous fishes: their significance in energy transfer in the deep-sea benthic ecosystem (Meriadzek Terrace-Bay of Biscay). Progress in Oceanography, 24, $223-237$.

Mauchline, J., \& Gordon, J. D. M. (1984). Diet and bathymetric distribution of the macrourid fish of the Rockall Trough, northeastern Atlantic Ocean. Marine Biology, 81, 107-121.

McConnaughey, T., \& McRoy, C. P. (1979). ${ }^{13} \mathrm{C}$ label identifies eelgrass (Zostera marina) carbon in an Alaskan estuarine food web. Marine Biology, 53, 263-269.

McKenzie, J. D. (1984). The tentacular ultrastructure of dendrochirote holothurians: a comparative SEM study. In B. F. Keegan, \& B. D. S. O'Connor, Proceedings of the $5^{\text {th }}$ international echinoderm conference, Galway (pp. 445-450). Rotterdam: Balkema.

Michener, R. H., \& Schell, D. M. (1994). Stable isotope ratios as tracers in marine aquatic food webs. In K. Lajtha, \& R. H. Michener, Stable isotopes in ecology and environmental science (pp. 138-157). Oxford: Blackwell Scientific Publications.

Minagawa, M., \& Wada, E. (1984). Stepwise enrichment of ${ }^{15} \mathrm{~N}$ along food chains: further evidence and relation between $\delta^{15} \mathrm{~N}$ and animal age. Geochimica et Cosmochimica Acta, 48, 1135-1140.

Monteiro, P. M. S., James, A. G., Sholto-Douglas, A. D., \& Field, J. G. (1991). The $\delta^{13}$ C trophic position isotope spectrum as a tool to define and quantify carbon pathways in marine food webs. Marine Ecology Progress Series, 78, 33-40.

Moore, H. M., \& Roberts, D. (1994). Feeding strategies in abyssal holothurians. In B. David, A. Guille, J.-P. Féral, \& M. Roux, Echinoderms through time (pp. 531-537). Rotterdam: Balkema.

Owens, N. J. P. (1987). Natural variations in ${ }^{15} \mathrm{~N}$ in the marine environment. Advances in Marine Biology, 24, 389-451.

Patching, J. W., \& Eardly, D. (1997). Bacterial biomass and activity in the deep waters of the eastern Atlantic-evidence of a barophilic community. Deep-Sea Research I, 44, 1655-1670.

Pawson, D. L. (1985). Psychropotes hyalinus, new species, a swimming elasipod sea cucumber (Echinodermata: Holothuroidea) from the north central Pacific Ocean. Proceedings of the Biological Society of Washington, 98, 523-525.

Peterson, B. J., \& Fry, B. (1987). Stable isotopes in ecosystem studies. Annual Review of Ecology and Systematics, 18, $293-320$.

Pfannkuche, O. (1993). Benthic response to sedimentation of particulate organic matter at the BIOTRANS station $47^{\circ} \mathrm{N}, 20^{\circ} \mathrm{W}$. DeepSea Research I, 40, 135-149.

Rau, G. H. (1981). Hydrothermal vent clam and tubeworm ${ }^{13} \mathrm{C} /{ }^{12} \mathrm{C}$ : Further evidence of non-photosynthetic food sources. Science, $213,338-340$.

Rau, G. H. (1982). The relationship between trophic level and stable isotopes of carbon and nitrogen. In W. Bascom, Coastal water research project biennial report for the years 1981-1982 (pp. 143-148). Long Beach: South California Water Research Project.

Rau, G. H., \& Hedges, J. I. (1979). Carbon-13 depletion in a hydrothermal vent mussel: suggestions of a chemosynthetic food source. Science, 203, 648-649.

Rau, G. M., Heyraud, M., \& Cherry, R. D. (1989). ${ }^{15} \mathrm{~N} /{ }^{14} \mathrm{~N}$ and ${ }^{13} \mathrm{C} /{ }^{12} \mathrm{C}$ in mesopelagic shrimp from the northeast Atlantic Ocean: evidence for differences in diet. Deep-Sea Research, 36 (7), 1103-1110.

Rau, G. H., Mearns, A. J., Young, D. R., Olson, R. J., Schafer, H. A., \& Kaplan, I. R. (1983). Animal ${ }^{13} \mathrm{C} /{ }^{12} \mathrm{C}$ correlates with trophic level in pelagic food webs. Ecology, 64, 1314-1318.

Rau, G. H., Teyssie, J.-L., Rassoulzadegan, F., \& Fowler, S. W. (1990). ${ }^{13} \mathrm{C} /{ }^{12} \mathrm{C}$ and ${ }^{15} \mathrm{~N} /{ }^{14} \mathrm{~N}$ variations among size fractionated marine particles: implications for their origin and trophic relationships. Marine Ecological Progress Series, 59, 33-38.

Reiswig, H. M. (1975). Bacteria as food for temperate-water marine sponges. Canadian Journal of Zoology, 53, 582-589.

Rice, A. L., Billett, D. S. M., Fry, J., John, A. W. G., Lampitt, R. S., Mantoura, R. F. C., \& Morris, R. J. (1986). Seasonal deposition of phytodetritus to the deep-sea floor. Proceedings of the Royal Society of Edinburgh, 88B, 265-279.

Rice, A. L., \& Lambshead, P. J. D. (1994). Patch dynamics in the deep-sea benthos: the role of a heterogeneous supply of organic matter. In P. S. Giller, A. G. Hildrew, \& D. G. Raffaelli, Aquatic ecology, scale, pattern and process (pp. 469-497). Oxford: Blackwell Scientific Publications.

Rice, A. L., Thurston, M. J. H., \& Bett, B. J. (1994). The IOSDL DEEPSEAS program: introduction and photographic evidence for the presence and absence of a seasonal input of phytodetritus at contrasting abyssal sites in the northeastern Atlantic. Deep-Sea Research, 41, 1305-1320.

Riemann-Zürneck, K. (1997). A hemisessile sea anemone from the Porcupine Abyssal Plain, north Atlantic ocean: Iosactis vagabunda gen. nov., sp. nov. Journal of the Marine Biological Association UK, 77, 1011-1025. 
Roberts, D. (1979). Deposit-feeding mechanisms and resource partitioning in tropical holothurians. Journal of Experimental Marine Biology and Ecology, 37, 45-56.

Roberts, D., \& Bryce, C. (1982). Further observations on tentacular feeding mechanisms in holothurians. Journal of Experimental Marine Biology and Ecology, 59, 151-163.

Roberts, D., \& Moore, H. M. (1997). Tentacular diversity in deep-sea deposit-feeding holothurians: implications for biodiversity in the deep-sea. Biodiversity and Conservation, 6, 1487-1505.

Roberts, D., Moore, H. M., Berges, J., Patching, J. W., Carton, M. W., \& Eardly, D. F. (2001). Sediment distribution, hydrolytic enzyme profiles and bacterial activities in the guts of Oneirophanta mutabilis, Psychropotes longicauda and Pseudostichopus villosus: what do they tell us about digestive strategies of abyssal holothurians? Progress in Oceanography, 50, 443-458.

Rowe, G. T. (1983). Biomass and production of the deep-sea macrobenthos. In G. T. Rowe, The sea, 8 (pp. 97-121). New York: Wiley-Interscience.

Sanders, H. L. (1968). Marine benthic diversity: a comparative study. American Naturalist, 102, $243-282$.

Santos, V., Billett, D. S. M., Rice, A. L., \& Wolff, G. A. (1994). The fate of organic matter in deep sea sediments from Porcupine Abyssal Plain. 1. Lipids. Deep-Sea Research, 41, 787-819.

Smith, K. L. (1987). Food energy supply and demand: a discrepancy between particular organic carbon flux and sediment community oxygen consumption in the deep ocean. Limnology and Oceanography, 32, 201-220.

Smith, C. R. (1992). Factors controlling bioturbation in deep-sea sediments and their relation to models of carbon diagenesis. In G. T. Rowe, \& V. Pariente, Deep-sea food chains and the global carbon cycle (pp. 375-393). Dordrecht: Kluwer Academic Publishers.

Smith, K. L., \& Hinga, K. R. (1983). Sediment community respiration in the deep-sea. In G. T. Rowe, The sea, 8 (pp. 331-370). New York: Wiley-Interscience.

Snider, L. J., Burnett, B. B., \& Hessler, R. R. (1984). The composition and distribution of meiofauna and nanobiota in a central North Pacific deep-sea area. Deep-Sea Research, 31A, 93-102.

Soetaert, K., \& Heip, C. (1989). The size of nematode assemblages along a Mediterranean deep-sea transect. Deep-Sea Research, 36A, 93-102.

Sokolova, M. N. (1997). Trophic structure of abyssal macrobenthos. Advances in Marine Biology, 32, 427-525.

Thiel, H. (1983). Meiobenthos and nanobenthos of the deep sea. In G. T. Rowe, The sea, 8 (pp. 167-230). New York: Wiley-Interscience.

Thurston, M. H. (1990). Abyssal necrophagous amphipods (Crustacea; Amphipoda) in the northeast and tropical Atlantic Ocean. Progress in Oceanography, 24, 257-274.

Thurston, M. H., Bett, B. J., Rice, A. L., \& Jackson, P. A. B. (1994). Variations in the invertebrate abyssal megafauna in the North Atlantic Ocean. Deep-Sea Research I, 41, 1321-1348.

Tieszen, L. L., Boutton, T. W., Tesdahl, K. G., \& Slade, N. A. (1983). Fractionation and turnover of stable carbon isotopes in animal tissues: Implications for $\delta^{13} \mathrm{C}$ analysis of diet. Oecologia, 57, 32-37.

Tietjen, J. H. (1992). Abundance and biomass of metazoan meiobenthos in the deep-sea. In G. T. Rowe, \& V. Pariente, Deep-sea food chains and the global carbon cycle (pp. 45-62). Dordrecht: Kluwer Academic Publishers.

Tyler, P. A., \& Billett, D. S. M. (1987). The reproductive ecology of elasipodid holothurians from the NE Atlantic. Biological Oceanography, 5, 273-296.

Vacelet, J., \& Boury-Esnault, N. (1995). Carnivorous sponges. Nature, London, 373, 333-338.

Van Dover, C. L., \& Fry, B. (1987). Stable isotopic compositions of hydrothermal vent organisms. Marine Biology, 102, $257-263$.

Van Dover, C. L., \& Fry, B. (1994). Microorganisms as food resources at deep-sea hydrothermal vents. Limnology and Oceanography, 39 (1), 51-57.

Vanreusel, A., Vincx, M., Bett, B. J., \& Rice, A. L. (1995). Nematode biomass spectra at two abyssal sites in the NE Atlantic with a presumed contrasting food supply. Internationale Revue der gesamten Hydrobiologie, 80 (2), 287-296.

Vincx, M., Bett, B. J., Dinet, A., Ferrero, T., Gooday, A. J., Lambshead, P. J. D., Pfannkuche, O., Soltwedel, T., \& Vanreusel, A. (1994). Meiobenthos of the deep Northeast Atlantic. Advances in Marine Biology, 30, 1-88.

Wada, E., Terazaki, M., Kabaya, Y., \& Nemoto, T. (1987). ${ }^{15} \mathrm{~N}$ and ${ }^{13} \mathrm{C}$ abundances in the Antarctic Ocean with emphasis on the biogeochemical structure of the food web. Deep-Sea Research, 34, 829-841.

Wakeham, S. G., Hedges, J. I., Lee, C., Peterson, M. L., \& Hernes, P. J. (1997). Compositions and transport of lipid biomarkers through the water column and surficial sediments of the equatorial Pacific Ocean. Deep-Sea Research II, 44, 2131-2162.

Whitehead, P. J. P., Bauchot, M.-L., Hureau, J.-C., Nielsen, J., \& Tortonese, E. (1986). Fishes of the north-eastern Atlantic and Mediterranean, 1-3. Paris: UNESCO. 